UDC: $378.147+37.026$

\title{
DEVELOPING FUTURE ACCOUNTANTS' PROFESSIONAL COMPETENCY THROUGH CONTENT AND LANGUAGE INTEGRATED LEARNING
}

\author{
Bodnar S. \\ sv.bodnar@ukr.net \\ https://orcid.org/0000-0002-9890-327X \\ Odessa Institute of Trade and Economics \\ of Kyiv National University of Trade and Economics \\ Paper received 07.07.2020. Accepted for publication 27.08.2020.
}

\begin{abstract}
The major concern of higher education institutions nowadays is to consider how to design new instructional approaches to developing interconnected professional and foreign language competence of students majoring in accounting. The detailed analysis of the present-day scientific works proves that content and language integrated learning (CLIL) is considered one of the widely-spread approaches in achieving this aim. In the present paper, the author tries to confirm this idea concerning training future Ukrainian accountants and draws on examining the effect of CLIL syllabus at Odesa Trade and Economics institute of Kiev National Trade and Economics University and Odessa National University of Economics. The programme included integrated learning a foreign language and "Macroeconomics" as a major subject. The programme duration was 4 months. A total of 108 students majoring in accounting participated in the programme of integrated learning. After the completion of the programme the students' professional knowledge and foreign language proficiency were assessed and their feedback collected and analyzed. Data were obtained from multiple sources, including interviews, pre-and-post assessment tests of language and professional proficiency. Results indicated significant advantages of CLIL regarding future accountants' competence in a foreign language and a major subject.
\end{abstract}

Key words: content and language integrated learning (CLIL), foreign language proficiency, professional proficiency, future accountants.

Боднар С. В. Формування професійної компетентності майбутніх фахівців з бухгалтерського обліку засобом інтегрованого навчання

Анотація. Bcmyn. Сучасний етап розвитку суспільства характеризується стрімким збільшенням кількості інформації в багатьох галузях знань, а також розвитком нових наукових напрямів. Забезпечити студентів новими знаннями в галузях, що виникають, і при цьому не ущемити їхній інтерес у вивченні основних дисциплін, які вже входять в навчальні програми, $є$ нереальним через неможливості збільшення навчального навантаження. Тому шлях вирішення такої суперечності між зростаючими потоками інформації, обов'язкової для пізнання молоддю, і браком часу на $\dddot{11}$ засвоєння, можна знайти в процесі злиття суміжних галузей знань в єдину предметну цілісність. 3 огляду на це метюю роботи є формування професійної компетентності українських студентів засобом інтегрованого навчання. Для досягнення названої мети використовувалися: $\boldsymbol{м е т о д ~ в и в ч е н н я ~ т а ~ а н а л і з у ~ н а у к о в о і ̈ ~ л і т е р а т у р и ~ з а ~ т е м о ю ~ д о с л і д ж е н н я ~ т а ~ м е т о д ~ м о д е л ю в а н н я ~ п р о ц е с у ~}$ навчання майбутніх фахівців з бухгалтерського обліку засобом предметно-мовного інтегрованого навчання. Результати проведеного дослідження дали нам змогу визначити певні стратегії з формування професійної компетентності майбутніх фахівців з бухгалтерського обліку, а саме: 1) вивчення змісту фахового предмета здійснюється лише іноземною мовою, але з можливістю продовжувати спілкування з викладачем за темою, що вивчається, за допомогою он-лайн чату (єдиною умовою є спілкування тільки англійською мовою); 2) студентам пропонуються різні версії одного й того самого англійського професійного тексту (адаптована версія, напівадаптована версія та автентична версія) залежно від рівня знання іноземної мови; 3) професійні автентичні тексти за темою лекції, які відібрані з різних економічних джерел, рекомендуються для самостійного вивчення студентами і їх стислого обговорення під час занять; 4) обов'язкове стисле 
повторення усіх частин матеріалу (як професійних, так і лінгвістичних) у процесі вивчення подальших тем; 5) робота з електронними кейсами як практичне застосування набутих знань. Ми дійшли висновків, що впровадження предметно-мовного інтегрованого навчання підвищує ефективність і мотивацію навчального процесу і сприяє формуванню професійної компетентності та іншомовних умінь майбутніх фахівців облікової справи.

Ключові слова: предметно-мовне інтегроване навчання, володіння іноземною мовою, професійна майстерність, майбутні фахівці з бухгалтерського обліку.

Боднар С. В. Одесский торгово-экономический институт Киевского национального торговоэкономического университета

Формирование профессиональной компетентности будущих бухгалтеров посредством интегрированного обучения

Аннотация. В статье раскрывается проблема формирования профессиональной компетентности будущих специалистов в сфере учета и аудита посредством предметно-языкового интегрированного обучения. Современный этап развития общества характеризуется стремительным притоком информации во многих ранее существующих областях знаний, а также развитием новых научных направлений. Обеспечить студентов знаниями о новых открытиях во вновь возникаемых отраслях науки, техники и производства не представляется реальным из-за невозможности увеличения учебной нагрузки. Поэтому решение проблемы предлагается в слиянии смежных областей знания в единую предметную целостность, а именно иностранный язык и предмет профессиональной направленности (в нашем случае, предмет по специальности “Экономика”). Определены основные стратегии, которые следует учитывать при интегрированном обучении будущих специалистов в сфере учета и аудита. Представлены результаты экспериментального обучения. Ключевые слова: предметно-языковое интегрированное обучение, владение иностранным языком, профессиональное мастерство, будущие специалисты в сфере учета и аудита.

Introduction (problem statement). The rapid integration of Ukraine into the European Union, expansion of international cooperation, increasing contacts with the representatives of the other countries in economic sphere have brought to the idea of renovating the requirements to the professional training of future economists who are supposed to speak a foreign language at the advanced level to be competitive at the world labour market. The State Education Development Programme of Ukraine until 2021 and National State Education Standards of higher education emphasize that graduates obtaining business and commerce degrees must have generic and professional competences along with a foreign language competence to communicate effectively in a professional domain.

To find appropriate ways to solve this problem, we focused our attention on the content and language integrated learning (CLIL) as an effective training approach which is widely accepted in the western countries nowadays. According to Tarnopolsky (2012), "integration" is a process that ensures parallel acquisition of knowledge from certain non-linguistic disciplines together with the acquisition of the target language and the skills of communicating in it (p. 73). The term content and language integrated learning was introduced by Marsh (2002) who stated that every kind of language learning in which a target language is also used for teaching students non-linguistic content could be called CLIL (p. 15). Its dual-focused character is considered to be a challenge both for teachers and students as it represents a combination of learning a major subject context and a foreign language (Leshchenko \& Halatsyn, 2018, p. 17). CLIL includes the subject specific vocabulary, grammatical structures and functional expressions needed for gaining knowledge of a curricular subject and communicating ideas (Bentley, 2010).

The analysis of recent research and publications. Different aspects of CLIL have been researched lately: genre-based pedagogy to facilitate students' learning of content knowledge and academic literacy (Yuen \& Heeseon, 2018); initiation-response-feedback approach as a technique to ensure meaningful communication (Campuzano, 2018); use of 3D multi-user virtual environment as Open stimulator which entails a tour of the students' avatars on a virtual island (Fokides \& Zampouli, 2017); technology-enhanced content and language integrated learning, in particular, use of Wikispaces 
and Knowledge Forum as virtual collective knowledge construction spaces (Zhao \& Lei, 2017) and use of wiki tools in out-of-class and in-class activities and collaborative learning within the subject of Social Science (Froldova \& Simonova, 2016).

The challenge of teaching professionally oriented oral and written communication in English using integrated approach has also inspired Ukrainian scholars who explored the subject in a number of works. They have investigated the application of CLIL while acquiring the knowledge of such non-linguistic disciplines as: "Engineering Technology" (Popel, 2015), "High math" (Lazorenko, 2016); "Pharmacy" (Horpinich, 2014); "Basics of economics" (Bodnar, 2016); "Navigation" (Primina, 2017). However, it didn't solve all the problems and unfortunately, didn't come into the mass education in Ukraine.

Thus, the purpose of our study is to examine the implementation of CLIL for training future accountants in Ukrainian tertiary schools and to determine the strategies of its effective application in the process of training. In the research, the following methods were applied: the comparison and system analysis of psychological, pedagogical, methodological sources; education process monitoring; modelling of the education process within the concept of CLIL; experimental training of students majoring in accounting; the data processing. Thus, the relevance of the research is based on the needs to train students majoring in accounting, who will be able to communicate fluently in English on the professional topics.

The results of the study. The conducted research was carried out in Ukraine in two state higher education institutions (Odesa Trade and Economics Institute and Odesa National University of Economics) at the accounting faculties. The 2nd-year students, who had the initial levels B1-B2 of the English language proficiency according to the Common European Framework of Reference for Languages and gave a written consent to participate in the research, joined the experimental course. Overall, 108 students of specialty 071 "Accounting and Taxation" were enrolled.

The research was based on the author's CLIL course for the 2nd-year students created on the basis of the major subject "Macroeconomics". It embraced lecture material, which consisted of such themes as: "Introduction to macroeconomics; Output and income; Inflation and deflation; Monetary policy, Accounting by types of economic activity, Accounting policy of the enterprise"; the terminological vocabulary given in various lexical combinations and linguistic environments with the examples from the "Financial Times"; accounting information presented in interactive schemes, tables, diagrams; authentic accounting documents, statements; electronic cases which help to activate professional knowledge and to develop oral skills in English; tasks for students' reasoning, idea interpreting, brainstorming. The texts of the lectures were constructed in such a way that the terminological vocabulary was constantly repeated from text to text ensuring its multiple use, that is considered obligatory according to Martynova's (2017) theory of complete mastering the linguistic material. The textual material gradually increased in volume, including both new information and information from the previous theme. Such organization of the material helped the students to understand the interconnection between the parts of the professional material and master the linguistic material.

The research data were collected using the following measurement instruments: interviewing, pre- and post- course assessment which included the measurement of the students' language and professional proficiency. The following criteria of the measurement according to the aim of the research were chosen: 1) linguistic - to check general language skills and occupational language skills; 2) professional - to check subject matter theoretical knowledge and subject matter practical skills. The indicators of assessment criteria of students' skills were measured by the means of 100 scores according to the ECTS scale that uses gradation of A, B, C, D, E, F.

The pre- and post-course tests had a similar structure during all stages of the assessment and similar professional and linguistic content for both groups: EG (experimental group) and CG (control group). The pre-course tests were held at the beginning of the academic year (in September), 
the post-course tests were held at the end of the semester (in December) during class time and consisted of 2 parts: tests on language proficiency and assignments on subject matter (theoretical knowledge and practical skills). The data were analysed using Microsoft Excel 2010. The pre-tests consisted of 5 topics which the students had learned the previous year according to their university curriculum: "Economy and economics", "Financial institutions", "Globalization in Business", "History of companies", "Competition in business". The language proficiency was verified by means of lexical testing based on the learned material (economic terms / notions, terminological phrases / sentences, sociocultural items). The tasks were: to match, to fill in the gaps, to choose the correct variant, to give own variant to the question. The professional proficiency was verified by means of doing the professional assignments in English. The tasks were: to choose the correct definition of the economic phenomena, explain the accounting notions, answer the subject questions, solve economic problems, fill in the statements.

The CLIL course lasted one semester (2018-2019) and had 56 hours of in-class activities along with 50 hours of self-study. The classes were held 2 times a week. All students were divided into two groups: EG which studied according to the CLIL programme and CG which learned ESP and major subjects (in Ukrainian) according to the specialty training curriculum. Both groups consisted of 54 students each. In the CG groups, two teachers (a lecturer in economics and an English teacher) provided the educational process. In the EG, the CLIL classes were held according to the curriculum of the major subject (lectures and seminars) in English. One teacher who was provided with the corresponding teaching materials (the author's CLIL course) and methodological guidelines how to conduct effective CLIL, developed by Martynova, Bodnar (2017) conducted these classes. The programme requirements for the students of the second course were identical for both groups.

The research was based on the following teaching strategies: 1) subject content learning was done only in a foreign language but with the opportunity to continue communicating with the teacher on the topic under study by means of on-line chatting in case of some misunderstanding of the material (the only condition was communication in English); 2) some versions of one and the same English professional text (adapted version, semi-adapted version and authentic version) were offered to the students; 3) professional authentic texts on the theme taken from different economic sources were recommended for students' independent reading; 4) compulsory revision of all parts of the material (both professional and linguistic) in the process of learning the subsequent topics; 5) work with electronic cases as a practical application of the obtained knowledge.

The experimental study was performed according to the University timetable and included the following. The lectures in the subject were conducted in English. At the beginning of each lecture future accountants got acquainted with the main professional linguistic material which was planned to be in the lecture. The English lecturer presented the key economic concepts, demonstrated the words usage in different professional environments, compiled a semantic concept map. This step is proved by the words of Cenoz (2015) who indicates that the language of the subject content should be accessible and understandable to provide mutual interaction. The introductory lecture was adapted to the level of students in a foreign language. To make the lecture material more available to the students, the lecturer accompanied his speech with Multimedia Presentation Software - Slide Dog to integrate sound, images, videos and animations to create memorable images of new professional items and engage students into the interactive learning process. Besides, during the lecture the students could send SMS text messaging to the lecturer with the questions arisen, the lecturer viewed these text messages on a computer screen, while he was giving a lecture, and paid more attention to that part of the material which turned to be unclear to the students.

At the next lecture a semi-adapted version of the lecture material with new information and partly with the revision of the previous one was presented. There was the distribution of handouts to the students to facilitate interaction during the lecturing process. These handouts provided the professional material for students to reflect upon, analyse, and discuss some points together 
in an interactive way. The mini-cases to solve were offered to the students to apply the ideas of the lecture into practice. At the end of the class, to check if the students achieved the learning objectives, they got the task to write the new items they learned.

A recorded authentic version of the lecture from London Business School was offered to the students as a self-study out-of-class work. After it they could discuss it in English with the lecturer by means of on-line chatting in case of some questions arising. The access to it was given through a University electronic library, web-based resources. The following parts of work were conducted identically. The main condition was compulsory revision of the professional material in the process of learning the subsequent topics. It was done in the way of questioning, furnishing with quizzes and short answers, solving mini-cases, presenting review slide-shows. At the seminars the students worked with topical electronic cases based on the authentic documentation of the enterprises as a practical application of the obtained language and professional knowledge, discussed disputable questions proving own points of view with the facts from the lecture material, analysing authentic articles taken out of different economic sources to compare the information, had meetings in English with the representatives of the Ukrainian accounting structure and foreign guests.

At the end of the semester the post-course test was conducted to measure the students' achievement. The pre-course assessment showed the following results. According to the linguistic criterion: 1) the average indicator of the level of general language skills in the students of the control group was 70 points (D) according to the ECTS scale, and the average indicator of the level of the general language skills in the students of the experimental group was 71 points (D);2) an average indicator of the level of the occupational language skills in the students of the control group was 65 points (E); an average indicator of the level of the occupational language skills in the students of the experimental group was the same -65 points (E).

According to the professional criterion: 1) the average indicator of the level of subject matter theoretical knowledge in the students of the control group was 64 points (E), and the average indicator of the level of the subject matter theoretical knowledge in the students of the experimental group was 63 points (E);2) the average indicator of the level of the subject matter practical skills in the students of the control group was 60 points (E), and the average indicator of the level of the subject matter practical skills in the students of the experimental group was 61 points (E).

The post-course assessment conducted after the completion of CLIL programme showed the following results. According to the linguistic criterion: 1) the average indicator of level of general language skills in the students of the control group was 74 points (remained at level D), while the average indicator of the level of the general language skills in the students of the experimental group was 80 points (increased to C); 2) the average indicator of the level of the occupational language skills in the students of the control group was 69 points (increased to D), while the average indicator of the level of the occupational language skills in the students of the experimental group was 76 points (increased to C).

According to the professional criterion: 1) the average indicator of the level of subject matter theoretical knowledge in the students of the control group was 68 points (increased to D), while the average indicator of the level of subject matter theoretical knowledge in the students of the experimental group was 78 points (increased to C); 2) the average indicator of the level of subject matter practical skills in the students of the control group was 65 points (remained at level E), while the average indicator of the level of the subject matter practical skills in the students of the experimental group was 75 points (increased to level C).

Table 1 shows the results of the tests before and after the course. 
Pre-and post-course assessment results

\begin{tabular}{|c|c|c|c|c|c|c|c|c|}
\hline \multirow[t]{4}{*}{ Groups } & \multicolumn{8}{|c|}{ Criteria } \\
\hline & \multicolumn{4}{|c|}{ Linguistic } & \multicolumn{4}{|c|}{ Professional } \\
\hline & \multicolumn{2}{|c|}{$\begin{array}{l}\text { General } \\
\text { language }\end{array}$} & \multicolumn{2}{|c|}{$\begin{array}{l}\text { Occupational } \\
\text { language }\end{array}$} & \multicolumn{2}{|c|}{$\begin{array}{l}\text { Subject matter } \\
\text { theoretical knowledge }\end{array}$} & \multicolumn{2}{|c|}{$\begin{array}{l}\text { Subject matter } \\
\text { practical skills }\end{array}$} \\
\hline & pre & post & pre & post & pre & post & pre & post \\
\hline EG & 71 & 80 & 65 & 76 & 63 & 78 & 61 & 75 \\
\hline $\mathrm{CG}$ & 70 & 74 & 65 & 69 & 64 & 68 & 60 & 65 \\
\hline
\end{tabular}

From table 1 it can be seen that the students of the EG demonstrated higher levels of language and professional proficiency than the students of the CG. The level of the general language skills increased by $9 \%$ in the EG and only by $4 \%$ in the CG; the level of the occupational language skills increased by $11 \%$ in the EG and by $4 \%$ in the CG; the level of subject matter theoretical knowledge increased by $15 \%$ in the EG and $4 \%$ in the CG; the level of subject matter practical skills increased by $14 \%$ in the EG and $5 \%$ in the CG. The percentage increase is shown in Table 2.

Table 2

Percentage increase of language proficiency and professional proficiency

\begin{tabular}{|c|c|c|c|c|}
\hline Groups & \multicolumn{3}{|c|}{ Percentage increase } \\
\hline & \multicolumn{2}{|c|}{ Linguistic } & \multicolumn{2}{c|}{ Professional } \\
\cline { 2 - 5 } & $\begin{array}{l}\text { General } \\
\text { language }\end{array}$ & $\begin{array}{l}\text { Occupational } \\
\text { language }\end{array}$ & $\begin{array}{l}\text { Subject matter } \\
\text { theoretical knowledge }\end{array}$ & $\begin{array}{l}\text { Subject matter } \\
\text { practical skills }\end{array}$ \\
\hline EG & 9 & 11 & 15 & 14 \\
\hline CG & 4 & 4 & 4 & 5 \\
\hline
\end{tabular}

At the end of the semester, the interviewing of EG students concerning their attitude to the CLIL programme was conducted. $95 \%$ of students positively evaluated this approach $(55 \%$ emphasised that they improved both language proficiency and professional knowledge; $23 \%$ stated that they started to understand the subject content much better; $9 \%$ said that they could easily make a professional report in English; $8 \%$ answered that they had already used English while interacting with foreign colleagues) and $5 \%$ showed an indifferent attitude. Thus, the conducted interviewing also confirmed the idea of introducing the CLIL programmes into the tertiary educational process.

Discussion. The discussion focuses on advantages and drawbacks of integrated learning in the University educational environment, the necessity of CLIL programme application in the Ukrainian universities and the strategies of effective content and language integrated learning.

The number of authors identified both advantages and disadvantages of CLIL. The most distinctive advantages are connected with: raising learner linguistic competence and confidence; increasing vocabulary learning skills and grammatical awareness; developing risk-taking and problem-solving skills in learners and teaching to learn through the foreign language (Coyle, 2007, p. 104-105); improving language performance in the target language without devoting extra time to teaching efforts (Karimi, Lotfi, \& Biria, 2017); increasing students' motivation to learning foreign languages and reflections on their professional experience (Lasagabaster, 2017); developing students' target language communication skills mostly subconsciously through their learning in the target language the content matter from the majoring subjects (Tarnopolsky, 2012); developing learners' cognitive flexibility, communication skills, meaningful interaction, skills for working life and intercultural awareness, and thus enhancing students' international academic mobility and employability for the labour market (Yang, 2017). It should be also noted that CLIL saves time within the overall curriculum. If content 
and language are learnt and taught in integration and not in isolation the time available for the teaching/ learning process of a content subject and a foreign language doubles; length of study time both for language and content subject can thus be reduced considerably, and as a consequence, more languages can be introduced into the curriculum (Wolff, 2003, p. 2). All these advantages testify that CLIL approach is of great help for developing students' professional and foreign language competences.

However, there are certain disadvantages, such as: real communication is not feasible in a classroom, and teacher-student interaction in CLIL education is very similar to parent-child interaction; a great focus is made on the content disregarding the language component of this approach (Campuzano, 2018); the possible decrease in the level of the subject matter is due to the oversimplification of the language because of the lack of learners' linguistic ability in the foreign language (Gonzalez, 2013); students lack basic words and expressions in English used in content subjects (Xiao, 2016); only the learners who have a high level of language proficiency feel satisfaction with the CLIL approach, the others experience discomfort trying to learn a subject-matter content in a foreign language (Yang, 2016).

In this research work the author tried to take into account the above-mentioned advantages and drawbacks and to develop the strategies which could be appropriate for Ukrainian students majoring in accounting. Firstly, the main drawback outlined by many scholars was connected with a "lack of professional terminology in English used in content subjects" (Xiao, 2016) or "oversimplification of the language" (Gonzalez, 2013) or "discomfort of trying to learn a subject content in a foreign language" (Yang, 2016), that's why the first part of every lecture was devoted to developing professional linguistic skills before starting work with the subject lecture material. Moreover, a compulsory revision of all the linguistic material under study was involved in the process of learning the subsequent themes and the text complexity was gradually increasing from an adapted version to semi-adapted version and later to authentic version. Secondly, not to have "parent-child interaction" (Campuzano, 2018), the students had interactive lectures where communication occurred in both directions and the students had an opportunity to be active participants in the learning process. Thirdly, to develop not only English listening comprehension skills (Dallinger, et al., 2016), the students had a self-study work during which they read various accounting texts on the theme under consideration taken from different authentic economic sources. Thus they developed English reading skills and got professional knowledge. Fourthly, the work with electronic cases had to prove that focus of learning was made not only on "the content disregarding the language component" (Campuzano, 2018) but on a foreign language too, using it for a practical application of the obtained knowledge while working with cases. Besides, the use of slide shows during the whole process of learning invested substantially into the CLIL by engaging the students into the interactive memorising process.

All these strategies had their way in the author's CLIL course on Macroeconomics presented in English which helped the students majoring in accounting develop communicative competences in professional interaction, eliminate the gap between language learning and major subjects, acquire the capacity to use every language unit in its maximum possible linguistic and professional environments, develop four language skills needed for future economists. Thus, we completely agree both with Bicknell, who posed a rhetoric question "Why we should teach Business English traditionally if CLIL can do it much more efficiently?” (2009, p.7), and with Dallinger, et al (2016) who, using a figure of speech, said that this method can kill two birds with one stone.

Conclusion and prospects for further research. The detailed analysis of scientific literature shows that CLIL has become an integral part of modern educational tendencies both in Ukraine and in the world, offering a wide range of possibilities for students. Such method opens up a new horizon for improving the Ukrainian education system and attention to diversity, as it provides resources and teaching aids with enormous potential for enhancing non-linguistic students' training. 
The analysis of the results of our study allowed us to single out some teaching strategies which showed the effectiveness of the CLIL programme introduction into training future accountants, namely: learning subject content in a foreign language and discussing it with the teacher by means of on-line chatting; using some versions of the English professional text (adapted version, semi-adapted version and authentic version); reading professional authentic texts on the theme taken from different economic sources to compare them; compulsory revising parts of the material (both professional and linguistic) in the process of learning the subsequent topics; working with electronic cases as a practical application of the obtained professional and linguistic knowledge. Through these strategies all the students were involved in professional activities in English and got an opportunity to proceed from training communication to a real business discourse.

We see the perspectives of our future research in exploring the process of CLIL implementation in Ukrainian high schools as a means of intensification of the teaching process.

\section{REFERENCES}

Bentley, K. (2010). The TKT course: CLIL module. Cambridge: Cambridge University Press.

Bicknell, H. (2009). Will CLIL kill BE? Business Issues, 72, 7-8.

Bodnar, S. (2016). Content and language integrated teaching to Ukrainian University students majoring in economics, Advanced Education, 6, 53-59. doi:10.20535/2410-8286.73872

Campuzano, J. M. (2018). Initiation-respond-feedback in content language integrated learning. Revista Universidad y Sociedad, 10 (4), 149-153. Retrieved February 24, 2019 from https://www.researchgate.net/publication/330672842_Initiation-Response-Feedback_in_Content_ Language_Integrated_Learning

Coyle, D. (2007). CLIL - a pedagogical approach from the European perspective. In N. van Deusen-Scholl and N. H. Hornberger (Eds). Encyclopedia of Language and Education. (Vol. 4, pp. 97-111). New York, NY: Springer. doi: 10.1007/978-0-387-30424-3_92

Dallinger, S., Jonkmann, K., Hollm, J., \& Fiege C. (2016, Feb.). The effect of content and language integrated learning on students' English and history competences - Killing two birds with one stone? Learning and instruction, 41, 23-31. doi: 10.1016/j.learninstruc.2015.09.003

González, J. M. (2013). (In)compatibility of CLIL and ESP courses at university. Language Value, 5 (1), 24-47. Retrieved from http://dx.doi.org/10.6035/LanguageV.2013

Fokides, E., \& Zampouli, C. (2017). Content and language integrated learning in OpenSimulator project. Results of a pilot implementation in Greece. Education and Information Technologies, 22 (4), 1479-1496. doi: 10.1007/s10639-016-9503-z

Froldova, V., \& Simonova, I. (2016). Teaching/learning social sciences through content and language integrated learning supported by Wiki tools. Advanced science letters, 22 (5-6), 1585-1588. doi: 10.1166/asl.2016.6692

Karimi, P., Lotfi, A. R., \& Biria, R. (2017). Efficacy of content and language integrated learning pedagogical techniques in improving aviation students' engagement in attaining specific learning outcomes. Journal of Teaching English for Specific and Academic Purposes, 5 (4), 781-791. doi: 10.22190/JTESAP1704781K

Lasagabaster, D. (2017). Integrated content and foreign language learning. What do CLIL students believe? Journal of Immersion and Content-based Language Education, 5 (1), 4-29. doi: 10.1075/jicb.5.1.01las

Leshchenko, M., Kochanowski, J., \& Lavrysh, Yu. (2018). The role of content and language integrated learning (CLIL) at Ukrainian and Polish educational systems: challenges and implication. Advanced Education, 9, 17-25. doi: 10.20535/2410-8286.1333409

Marsh, D. (2012). Content and language integrated learning (CLIL). A Development Trajectory. University of Cordoba. Retrieved February 20, 2018, from: helvia.uco.es/xmlui/bitstream/ handle/10396/8689/2013000000658.pdf?sequence $=1$ 
Martynova, R., \& Bodnar, S. (2017). Pedagogicheskiye osnovy integrirovannogo protsessa obucheniya obrazovatel'noy i inoyazychnoy rechevoy deyatel'nosti: Monografiya [Pedagogical bases of the integrated process of teaching educational and foreign speech activity: Monograph]. Odessa, Ukraine: Osvita.

Natsionalna stratehiya rozvytku osvity v Ukraina na period do 2021 roky [National Strategy for the Development of Education in Ukraine until 2021] (2013). Retrieved February, 24, 2019 from http://zakon3.rada.gov.ua/laws/show/344/2013\#n10

Tarnopolsky, O. (2012). Constructivist blended learning approach to teaching English for specific purposes. London, England: Versita. doi: 10.2478/9788376560014

Xiao, J. F. (2016). Integrated English in China - An effective CLIL model of foreign languages and cultures learning. International Journal of Innovation and Research in Educational Sciences, 3 (4), 234-242. Retrieved from https:/www. unifg.it/sites/default/files/ allegatiparagrafo/06-07-017/ xiao_integrated_english_in_china_an_effective_clil_model.pdf

Yang, W. (2016). An investigation of learning efficacy, $\bar{m}^{-}$management difficulties and improvements in tertiary CLIL programmes in Taiwan: A survey of stakeholder perspectives. Latin-American Journal of Content and Language Integrated LACLIL, 9 (1), 64-109. doi: 10.5294/lacli1.2016.9.1.4

Yang, W. (2017). Tuning University undergraduates for high mobility and employability under the content and language integrated learning approach. International Journal of Bilingual Education and Bilingualism, 20 (6), 607-624. doi: 10.1080/13670050.2015.1061474

Yuen, Yi., \& Heeseon, J. (2018, Oct.). Impact of genre-based pedagogy on students' academic literacy development in content and language integrated learning. Linguistics and Education, 47, 36-46. doi: 10.1016/j.linged.2018.08.001

Zhao, K., \& Lei, C. L. (2017). Technology-enhanced content and language integrated learning in Chinese tertiary English classes: Potentials and challenges. In Hayo Reinders, David Nunan and Bin Zou (Eds.), Innovation in Language Learning and Teaching: the Case of China (pp. 89-113). New Language Learning and Teaching Environments. doi: 10.1057/978-1-137-60092-9_5

Wolff, D. (2003). Integrating language and content in the language classroom: Are transfer of knowledge and of language ensured? ASp, 35-46. 